\title{
Pyridinolysis of Diisopropyl Chlorophosphate in Acetonitrile
}

\author{
Md. Ehtesham Ul Hoque and Hai Whang Lee* \\ Department of Chemistry, Inha University, Incheon 402-751, Korea. ${ }^{*}$-mail: hwlee@inha.ac.kr \\ Received July 21, 2011, Accepted July 26, 2011
}

Key Words : Phosphoryl transfer reaction, Pyridinolysis, Diisopropyl chlorophosphate, Biphasic concave upward free energy relationship

Continuing the kinetic studies of the pyridinolyses of dimethyl [1: $\left.(\mathrm{MeO})_{2} \mathrm{P}(=\mathrm{O}) \mathrm{Cl}\right],{ }^{1}$ diethyl $\left[2:(\mathrm{EtO})_{2} \mathrm{P}(=\mathrm{O}) \mathrm{Cl}\right]{ }^{1}$ and Y-aryl phenyl [4: $\left.(\mathrm{PhO})\left(\mathrm{YC}_{6} \mathrm{H}_{4} \mathrm{O}\right) \mathrm{P}(=\mathrm{O}) \mathrm{Cl}\right]^{2}$ chlorophosphates, the nucleophilic substitution reactions of diisopropyl chlorophosphate (3) with substituted X-pyridines are investigated kinetically in acetonitrile at $35.0 \pm 0.1{ }^{\circ} \mathrm{C}$ (Scheme 1) to gain further information into the reactivity and mechanism depending on the variation of the two ligands, $\mathrm{R}_{1} \mathrm{O}$ and $\mathrm{R}_{2} \mathrm{O}$, where $\mathrm{R}_{1}$ and $\mathrm{R}_{2}$ are alkyl and/or phenyl (aryl). The numbering of the substrates of 1-4 follows the sequence of the size of the two ligands, $\mathrm{R}_{1} \mathrm{O}$ and $\mathrm{R}_{2} \mathrm{O}$.

\section{Results and Discussion}

The reactions were carried out under pseudo-first-order conditions with a large excess of pyridine. The observed pseudo-first-order rate constants $\left(k_{\text {obsd }}\right)$ for all reactions obeyed eq. (1) with negligible $k_{0}(=0)$ in $\mathrm{MeCN}$. The second-order rate constants were determined with at least five pyridine concentrations. The linear plots of eq. (1) suggest a lack of any base-catalysis or side reactions, and the overall reaction is described by Scheme 1 .

$$
k_{\text {obsd }}=k_{0}+k_{2}\left[\mathrm{XC}_{5} \mathrm{H}_{4} \mathrm{~N}\right]
$$

The second-order rate constants $\left[k_{2}\left(\mathrm{M}^{-1} \mathrm{~s}^{-1}\right)\right]$ are summarized in Table 1 . The Brönsted $\beta_{\mathrm{X}}$ value was calculated by correlating $\log k_{2}(\mathrm{MeCN})$ with $\mathrm{p} K_{\mathrm{a}}\left(\mathrm{H}_{2} \mathrm{O}\right){ }^{3}$, which was justified theoretically and experimentally. ${ }^{4}$ The substituent

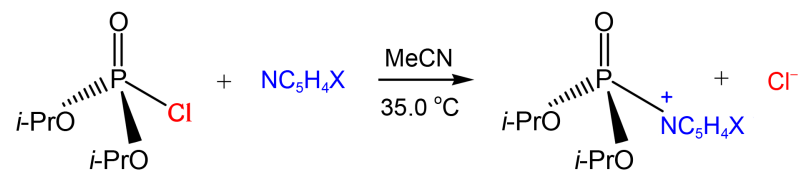

$\mathrm{X}=$ 4-MeO, 4-Me, 3-Me, H, 3-Ph, 3-MeO, 3-Cl, 3-Ac, 4-Ac, 3$\mathrm{CN}, 4-\mathrm{CN}$

Scheme 1. The studied reaction system. effects of the nucleophiles upon the pyridinolysis rates correlate with those for a typical nucleophilic substitution reaction where the stronger nucleophile leads to a faster rate. However, both the Hammett $\left(\log k_{2} v s \quad \sigma_{\mathrm{X}}\right.$; Fig. 1) and Brönsted [ $\log k_{2}$ vs $\mathrm{p} K_{\mathrm{a}}(\mathrm{X})$; Fig. 2] plots are biphasic concave upwards with a break point at $\mathrm{X}=3-\mathrm{Ph}$. The magnitudes of $\rho_{\mathrm{X}}(=-5.12)$ and $\beta_{\mathrm{X}}(=1.05)$ values with the strongly basic pyridines ( $\mathrm{X}=4-\mathrm{MeO}, 4-\mathrm{Me}, 3-\mathrm{Me}, \mathrm{H}, 3-\mathrm{Ph})$ are greater than those $\left(\rho_{\mathrm{X}}=-2.28\right.$ and $\left.\beta_{\mathrm{X}}=0.39\right)$ with the weakly basic pyridines ( $\mathrm{X}=3-\mathrm{Ph}, 3-\mathrm{MeO}, 3-\mathrm{Cl}, 3-\mathrm{Ac}, 4-\mathrm{Ac}$, 3-CN, 4-CN).

The second-order rate constants $\left(k_{2}\right)$ with unsubstituted pyridine $\left(\mathrm{C}_{5} \mathrm{H}_{5} \mathrm{~N}\right)$ at $35.0{ }^{\circ} \mathrm{C}$, natural bond order (NBO) charges at the reaction center $\mathrm{P}$ atom in the gas phase $[$ B3LYP/6-311+G(d,p) level of theory $],{ }^{5}$ summations of the Taft's steric constants $\left[\Sigma E_{\mathrm{S}}=E_{\mathrm{S}}\left(\mathrm{R}_{1}\right)+E_{\mathrm{S}}\left(\mathrm{R}_{2}\right)\right]^{6,7}$ of the two ligands, and Brönsted coefficients $\left(\beta_{\mathrm{X}}\right)$ for the pyridinolyses

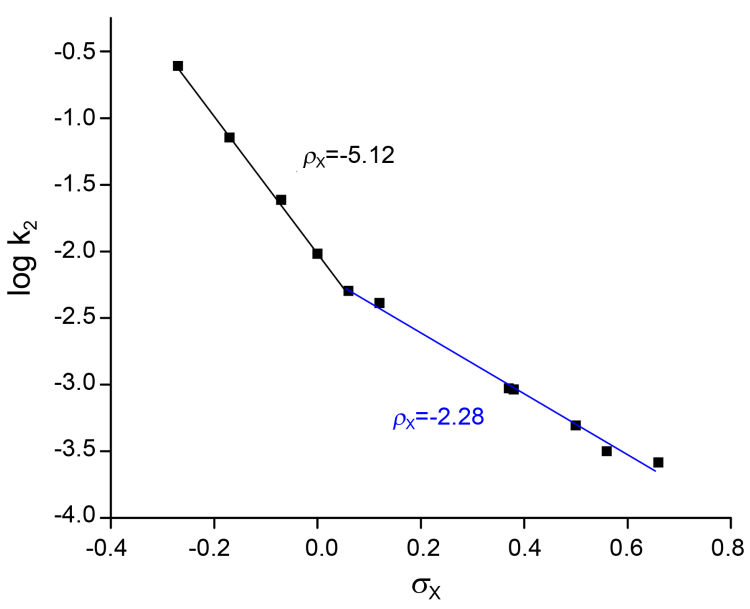

Figure 1. The Hammett plot $\left(\log k_{2} v s \sigma_{\mathrm{X}}\right)$ of the reactions of diisopropyl chlorophosphate (3) with X-pyridines in $\mathrm{MeCN}$ at 35.0 ${ }^{\circ} \mathrm{C}$. The values of $\rho_{\mathrm{X}}$ are $-5.12 \pm 0.02(\mathrm{r}=0.999)$ with $\mathrm{X}=(4-\mathrm{MeO}$, 4-Me, 3-Me, H, 3-Ph) and $-2.28 \pm 0.05(\mathrm{r}=0.996)$ with $\mathrm{X}=(3-\mathrm{Ph}$, 3-MeO, 3-Cl, 3-Ac, 4-Ac, 3-CN, 4-CN).

Table 1. Second-Order Rate Constants $\left(k_{2} \times 10^{3} / \mathrm{M}^{-1} \mathrm{~s}^{-1}\right)$ of the Reactions of Diisopropyl Chlorophosphate $(3)$ with $\mathrm{XC}_{5} \mathrm{H}_{4} \mathrm{~N}$ in $\mathrm{MeCN}_{\text {at }}$ $35.0^{\circ} \mathrm{C}$

\begin{tabular}{cccccccccccc}
\hline $\mathrm{X}$ & $4-\mathrm{MeO}$ & $4-\mathrm{Me}$ & $3-\mathrm{Me}$ & $\mathrm{H}$ & $3-\mathrm{Ph}$ & $3-\mathrm{MeO}$ & $3-\mathrm{Cl}$ & $3-\mathrm{Ac}$ & $4-\mathrm{Ac}$ & $3-\mathrm{CN}$ & $4-\mathrm{CN}$ \\
\hline$k_{2}$ & 246 & 71.5 & 24.3 & 9.60 & 5.04 & 4.10 & 0.938 & 0.919 & 0.494 & 0.316 & 0.260 \\
$\times 10^{3}$ & \pm 1 & \pm 0.1 & \pm 0.1 & \pm 0.01 & \pm 0.01 & \pm 0.01 & \pm 0.001 & \pm 0.002 & \pm 0.001 & \pm 0.001 & \pm 0.001 \\
\hline
\end{tabular}




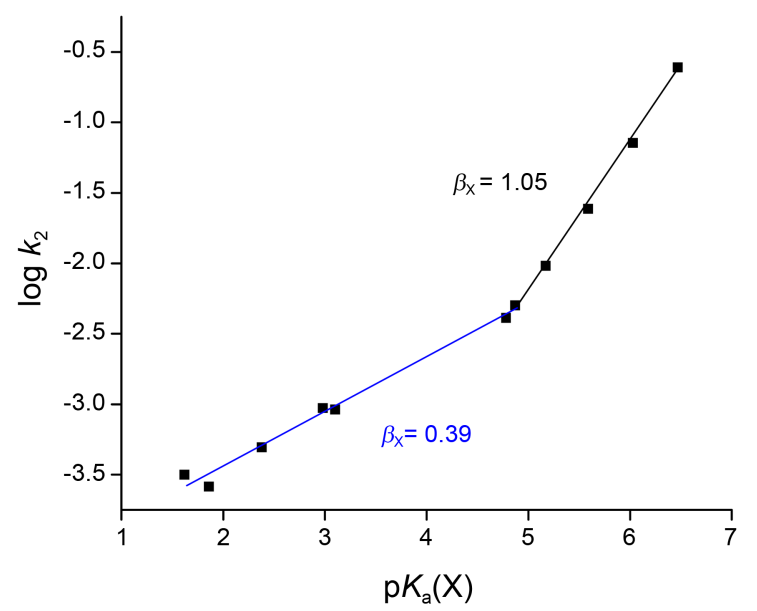

Figure 2. The Brönsted plot $\left[\log k_{2} v s \mathrm{p} K_{\mathrm{a}}(\mathrm{X})\right]$ of the reactions of diisopropyl chlorophosphate (3) with X-pyridines in $\mathrm{MeCN}$ at 35.0 ${ }^{\circ} \mathrm{C}$. The values of $\beta_{\mathrm{X}}$ are $1.05 \pm 0.04(\mathrm{r}=0.999)$ with $\mathrm{X}=(4-\mathrm{MeO}$, 4-Me, 3-Me, H, 3-Ph) and $0.39 \pm 0.06(\mathrm{r}=0.994)$ with $\mathrm{X}=(3-\mathrm{Ph}$, 3-MeO, 3-Cl, 3-Ac, 4-Ac, 3-CN, 4-CN).

of four $\left(\mathrm{R}_{1} \mathrm{O}\right)\left(\mathrm{R}_{2} \mathrm{O}\right) \mathrm{P}(=\mathrm{O}) \mathrm{Cl}$-type chlorophosphates in $\mathrm{MeCN}$ are summarized in Table 2. When the magnitude of the positive charge of the reaction center $P$ atom in the substrate plays an important role to determine the pyridinolysis rate, the sequence of the pyridinolysis rate should be $\mathbf{3}>\mathbf{2}>\mathbf{4}>$ 1. On the other hand, when the steric effects of the two ligands, $\mathrm{R}_{1} \mathrm{O}$ and $\mathrm{R}_{2} \mathrm{O}$, play an important role, the sequence of the rate should be $\mathbf{1}>\mathbf{2}>\mathbf{3}>\mathbf{4}$. However, the observed sequence of the pyridinolyses rates of $\mathbf{4}>\mathbf{1}>\mathbf{2}>\mathbf{3}$ [the relative rate ratio of $28(\mathbf{4}): 6.7(\mathbf{1}): 5.5(2): 1(\mathbf{3})]$ does not show systematic consistency with the NBO charge at $\mathrm{P}$ atom or $\Sigma E_{\mathrm{S}}$. These results indicate that the pyridinolysis rates of $\left(\mathrm{R}_{1} \mathrm{O}\right)\left(\mathrm{R}_{2} \mathrm{O}\right) \mathrm{P}(=\mathrm{O})$ Cl-type substrates in $\mathrm{MeCN}$ are not dependent upon one dominant factor but on many factors. On the contrary, the anilinolysis rates of the chlorophsphates $^{8}$ are predominantly dependent upon the steric effects of the two ligands. The second-order rate constants for the reactions of four chlorophosphates with $\mathrm{C}_{6} \mathrm{H}_{5} \mathrm{NH}_{2}$ in $\mathrm{MeCN}$ at $55.0{ }^{\circ} \mathrm{C}$ gave the relative rate ratio of $6.0(1)^{8 b}: 4.0(2)^{8 b}$ : $1.3(\mathbf{4})^{8 \mathrm{a}}: 1(\mathbf{3}){ }^{8 \mathrm{c}}$ When $\mathbf{3}$ is not considered, the sequence of the anilinolysis rates of three chlorophosphates, $1>\mathbf{2}>\mathbf{4}$, is inversely proportional to the size of the two ligands; $\mathrm{PhO}, \mathrm{PhO}(\mathbf{4})>\mathrm{EtO}, \mathrm{EtO}(\mathbf{2})>\mathrm{MeO}, \mathrm{MeO}(\mathbf{1})$. The greater the size of the two ligands, the anilinolysis rate becomes slower, i.e., the relative rate ratio of $4.8(\mathbf{1})^{8 b}: 3.2(\mathbf{2})^{8 b}: 1(\mathbf{4}){ }^{8 a}$ indicating that the anilinolysis rate of $\mathbf{3}$ is somewhat slower than the expected one from the steric effects of the two ligands. The sequence of the anilinolysis rates of phosphinic chlorides $\left[\mathrm{R}_{1} \mathrm{R}_{2} \mathrm{P}(=\mathrm{O})\right.$ Cl-type where $\mathrm{R}_{1}$ and $\mathrm{R}_{2}$ are alkyl and/ or phenyl] ${ }^{9}$ is strongly dependent upon the steric effects of the two ligands and the relative rate ratio obtained is as follows: $4,520\left[\mathrm{Me}_{2} \mathrm{P}(=\mathrm{O}) \mathrm{Cl}\right]^{9 \mathrm{~b}}: 109\left[\mathrm{Et}_{2} \mathrm{P}(=\mathrm{O}) \mathrm{Cl}\right]^{9 \mathrm{c}}: 80$ $[\mathrm{MePhP}(=\mathrm{O}) \mathrm{Cl}]^{9 \mathrm{~b}}: 1\left[\mathrm{Ph}_{2} \mathrm{P}(=\mathrm{O}) \mathrm{Cl}\right]^{9 \mathrm{a}}$ in $\mathrm{MeCN}$ at $55.0{ }^{\circ} \mathrm{C}$. The sensitivity to the steric effects of the two ligands on the anilinolysis rates of phosphinic chlorides is much greater than that of chlorophosphates. It seems that the intervening oxygen atom between the reaction center $P$ atom and $R_{i}$ in chlorophosphates reduces the sensitivity to the steric effects of the two ligands on the anilinolysis rates. In other words, the ligand, $\mathrm{R}_{\mathrm{i}}$, is directly bonded to $\mathrm{P}$ atom in phosphinic chloride, while the $R_{i}$ group is bonded to the intervening oxygen atom which is bonded to $\mathrm{P}$ atom in chlorophosphate, and as a result, the available space for the attacking aniline in chlorophosphate is greater than that in phosphinic chloride. As seen in Table 2, the pyridinolysis rate of $\mathbf{3}$ is more or less slow as in the anilinolysis rate. The authors tentatively suggest that the slow rate of the aminolysis of $\mathbf{3}$ is attributed to the exceptional ground state stabilization.

Meanwhile, the pyridinolysis rate is rather faster than the corresponding anilinolysis rate in $\mathrm{MeCN}: k_{\mathrm{Pyr}}\left(35.0^{\circ} \mathrm{C}\right) /$ $k_{\mathrm{An}}\left(55.0^{\circ} \mathrm{C}\right)=15(1),{ }^{1,8 \mathrm{~b}} 19(2),{ }^{1,8 \mathrm{~b}} 14(3),{ }^{8 \mathrm{c}}$ and $300(4),{ }^{2,8 \mathrm{a}}$ Note that the reaction temperatures are 35.0 and $55.0{ }^{\circ} \mathrm{C}$ for the pyridinolysis and anilinolysis, respectively. The difference in the rate may be due to resonance energy gain from the benzyl cation type $\pi$-complex formation of pyridine with an empty d-orbital of the $\mathrm{P}$ atom. This type of $\pi$-complex is not possible with aniline because the lone pair on the amino nitrogen is a p-type so that the horizontal $\pi$-cloud of the ring overlap with the d-orbital of P marginally. Moreover, regarding the steric effects of the two ligands, the horizontal approach of the aniline ring should cause excessive steric hindrance in contrast to a much less steric effects in the vertical approach of the pyridine ring., ${ }^{2,10}$

A concerted mechanism with an early transition state (TS) involving backside nucleophilic attack TSb toward the $\mathrm{Cl}$ leaving group (Scheme 2) was proposed on the basis of small negative cross-interaction constant $\left(\rho_{\mathrm{XY}}=-0.15\right)^{11,12}$ and small values of Brönsted coefficients $\left(\beta_{\mathrm{X}}=0.16-0.18\right)$ for the pyridinolysis of $4 .^{2}$ The $\mathrm{S}_{\mathrm{N}} 2$ reaction mechanism was

Table 2. Summary of the Second-Order Rate Constants $\left(k_{2}\right.$ with $\mathrm{C}_{5} \mathrm{H}_{5} \mathrm{~N}$ at $\left.35.0{ }^{\circ} \mathrm{C}\right)$, NBO Charges at the Reaction Center P Atom, Summations of the Taft's Steric Constants $\left(\Sigma E_{\mathrm{S}}\right)$ of the Two Ligands, and Brönsted Coefficients $\left(\beta_{\mathrm{X}}\right)$ for the Pyridinolyses of 1, 2, 3, and $\mathbf{4}$ in $\mathrm{MeCN}$

\begin{tabular}{cccccc}
\hline Substrate & $k_{2} \times 10^{3 a}$ & Charge at $\mathrm{P}$ & $-\Sigma E_{\mathrm{S}}$ & $\beta_{\mathrm{X}}$ & Ref \\
\hline $\mathbf{1 :}(\mathrm{MeO})_{2} \mathrm{P}(=\mathrm{O}) \mathrm{Cl}$ & 64.7 & 2.226 & 0 & 0.63 & 1 \\
$\mathbf{2 :}(\mathrm{EtO})_{2} \mathrm{P}(=\mathrm{O}) \mathrm{Cl}$ & 52.8 & 2.236 & 0.14 & 0.73 & 1 \\
3: $\left.(i-\mathrm{PrO})_{2} \mathrm{P}=\mathrm{O}\right) \mathrm{Cl}$ & 9.60 & 2.269 & 0.94 & $1.05^{d} / 0.39^{e}$ & this work \\
4: $\left.\mathrm{PhO}\left(\mathrm{YC}_{6} \mathrm{H}_{4} \mathrm{O}\right) \mathrm{P}=\mathrm{O}\right) \mathrm{Cl}$ & $266^{b}$ & $2.230^{c}$ & 4.96 & $0.16-0.18$ & 2 \\
\hline
\end{tabular}

${ }^{a}$ Second-order rate constant with unsubstituted pyridine $(\mathrm{X}=\mathrm{H})$ at $35.0^{\circ} \mathrm{C} .{ }^{b}$ Extrapolated value in the Arrhenius plot with kinetic data: $k_{2}=37.1,94.0$, and $135 \times 10^{-3} \mathrm{M}^{-1} \mathrm{~s}^{-1}$ at $5.0,15.0$, and $25.0^{\circ} \mathrm{C}$, respectively, from ref. $2{ }^{c}$ The value with $\mathrm{Y}=\mathrm{H} .{ }^{d} \mathrm{X}=4-\mathrm{MeO}, 4-\mathrm{Me}, 3-\mathrm{Me}, \mathrm{H}, 3-\mathrm{Ph} .{ }^{e} \mathrm{X}=3-\mathrm{Ph}, 3-\mathrm{MeO}$, 3-Cl, 3-Ac, 4-Ac, 3-CN, 4-CN. 

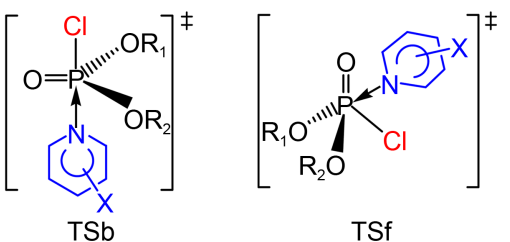

Scheme 2. Backside and frontside attack TS.

proposed for the pyridinolyses of $\mathbf{1}$ and $\mathbf{2}$ with both frontside TSf (Scheme 2) and backside attacks TSb, and the fraction of a frontside attack is more or less larger than that of a backside attack, on the basis of the magnitudes of $\beta_{\mathrm{X}}$ values. ${ }^{1}$

In the present work, the free energy correlations for substituent $\mathrm{X}$ variations in the pyridines are biphasic concave upwards, while those of $\mathbf{1}, \mathbf{2}$, and $\mathbf{4}$ are linear. The concave upward Hammett and Brönsted plots with $\mathrm{X}$ were also observed for the pyridinolyses of following substrates: dimethyl phosphinic chloride; ${ }^{13}$ dicyclohexyl phosphinic chloride $\left[(\mathrm{cHex})_{2} \mathrm{P}(=\mathrm{O}) \mathrm{Cl}\right] ;{ }^{14}$ dimethyl thiophophinic chloride $\left[\mathrm{Me}_{2} \mathrm{P}(=\mathrm{S}) \mathrm{Cl}\right]{ }^{13}$ diethyl thiophosphinic chloride $\left[\mathrm{Et}_{2} \mathrm{P}(=\mathrm{S}) \mathrm{Cl}\right]{ }^{15}$ dimethyl chlorothiophosphate $\left[(\mathrm{MeO})_{2}-\right.$ $\mathrm{P}(=\mathrm{S}) \mathrm{Cl}] ;{ }^{1}$ diethyl chlorothiophosphate $\left[(\mathrm{EtO})_{2} \mathrm{P}(=\mathrm{S}) \mathrm{Cl}\right] ;{ }^{1}$ diphenyl thiophosphinic chloride $\left[\mathrm{Ph}_{2} \mathrm{P}(=\mathrm{S}) \mathrm{Cl}\right] .{ }^{16}$ The biphasic concave upward free energy relationships were interpreted as a change of the nucleophilic attacking direction from a frontside attack TSf with the strongly basic pyridines to a backside attack TSb with the weakly basic pyridines in a concerted process.

In general, the nonlinear free energy correlation of a concave upward plot is diagnostic of a change in the reaction mechanism, such as parallel reactions where the reaction path is changed depending on the substituents, while nonlinear free energy correlation of the biphasic concave downward plot is diagnostic of a rate-limiting step change from bond breaking with less basic nucleophiles to bond formation with more basic nucleophiles. ${ }^{17}$ It is the suggestion of the authors that the concave upward Hammett and Brönsted plots can also be diagnostic of a change in the attacking direction of the nucleophile depending on the substituents from backside to frontside. ${ }^{1}$ It is worthy to note that a frontside attack TSf yields greater magnitudes of $\rho_{\mathrm{X}}$ and $\beta_{\mathrm{X}}$ values compared to a backside attack. ${ }^{18}$

In the present work, thus, a concerted $\mathrm{S}_{\mathrm{N}} 2$ mechanism is proposed and biphasic concave upward free energy correlations is rationalized by a change of nucleophilic attacking direction from a frontside attack TSf $\left(\rho_{\mathrm{X}}=-5.12\right.$ and $\beta_{\mathrm{X}}=$ 1.05 ) with the strongly basic pyridines to a backside attack (TSb; $\rho_{\mathrm{X}}=-2.28$ and $\beta_{\mathrm{X}}=0.39$ ) with the weakly basic pyridines.

In summary, the kinetic studies on the pyridinolysis of diisopropyl chlorophosphate have been carried out in $\mathrm{MeCN}$ at $35.0^{\circ} \mathrm{C}$. The free energy correlations are biphasic concave upwards with a break point at $\mathrm{X}=3-\mathrm{Ph}$. A concerted $\mathrm{S}_{\mathrm{N}} 2$ mechanism is proposed with a change of the attacking direction of the X-pyridine from a frontside attack with the strongly basic pyridines to a backside attack with the weakly basic pyridines.

\section{Experimental Section}

Materals. Diisopropyl Chlorophosphate (97\%) was used without further purification. GR grade pyridines and HPLC grade acetonitrile (less than $0.005 \%$ water content) were used without further purification.

Kinetic Procedure. Conductometric rate measurements were carried out using self-made computer-aided automatic A/D converter conductivity bridges. ${ }^{1,2}$ Pseudo-first-order rate constants, $k_{\text {obsd, }}$, were measured by curve fitting analysis in origin program with a large excess of pyridines, [Substrate] $=1 \times 10^{-3} \mathrm{M}$ and [Pyridine] $=0.02-0.05 \mathrm{M}$. Second-order rate constants, $k_{2}$, were obtained from the slope of a plot of $k_{\text {obsd }} v s$. [X-Pyridine]. The Pseudo-first-order rate constant values $\left(k_{\text {obsd }}\right)$ were the average of three runs that were reproducible within $\pm 3 \%$.

Product Analysis. Diisopropyl Chlorophosphate was reacted with excess pyridine, for more than 15 half-lives at $35.0{ }^{\circ} \mathrm{C}$ in $\mathrm{MeCN}$. Acetonitrile was removed under reduced pressure. The product was isolated by adding ether and insoluble fraction was collected. The product was purified to remove excess pyridine by washing several times with ether. Analytical and spectroscopic data of the product gave the following results:

$\left[(i-\mathbf{P r O})_{2} \mathbf{P}(=\mathbf{O}) \mathbf{N C}_{5} \mathbf{H}_{5}\right]^{+} \mathbf{C l}^{-}$. Light-yellow gummy-substance; ${ }^{1} \mathrm{H}$ NMR $\left(400 \mathrm{MHz}, \mathrm{CDCl}_{3}\right) \delta 1.27-1.36(12 \mathrm{H}, \mathrm{m}$, $\left.4 \mathrm{CH}_{3}, i-\mathrm{Pr}\right), 4.67-4.78(2 \mathrm{H}, \mathrm{m}, 2 \mathrm{CH}, i-\mathrm{Pr}), 7.43$ (s, $2 \mathrm{H}$, pyridinium), $7.83(\mathrm{~s}, 1 \mathrm{H}$, pyridinium), $8.68(\mathrm{~s}, 2 \mathrm{H}$, pyridinium); ${ }^{13} \mathrm{C}$ NMR $\left(100 \mathrm{MHz}, \mathrm{CDCl}_{3}\right) \delta 23.38\left(\mathrm{CH}_{3}, i-\mathrm{Pr}\right), 74.05$ $(\mathrm{CH}, i$-Pr) $, 94.35,103.86,124.69,138.29,147.43(\mathrm{C}=\mathrm{C}$, pyridinium); ${ }^{31} \mathrm{P}$ NMR $\left(162 \mathrm{MHz}, \mathrm{CDCl}_{3}\right) \delta-9.79$ (s, $1 \mathrm{P}$, $\mathrm{P}=\mathrm{O}) ; m / z, 279\left(\mathrm{M}^{+}\right)$.

Acknowledgments. This work was supported by the Brain Korea 21 Program from National Research Foundation of Korea and Inha University Research Grant.

\section{References and Notes}

1. Dey, N. K.; Hoque, M. E. U.; Kim, C. K.; Lee, H. W. J. Phys. Org. Chem. 2010, 23, 1022.

2. Guha, A. K.; Lee, H. W.; Lee, I. J. Org. Chem. 2000, 65, 12.

3. (a) Fischer, A.; Galloway, W. J.; Vaughan, J. J. Chem. Soc. 1964, 3591. (b) Dean, J. A. Handbook of Organic Chemistry; McGrawHill: New York, 1987; Chapter 8. (c) Castro, E. A.; Freudenberg, M. J. Org. Chem. 1980, 45, 906.

4. (a) Lee, I.; Kim, C. K.; Han, I. S.; Lee, H. W.; Kim, W. K.; Kim, Y. B. J. Phys. Chem. B 1999, 103, 7302. (b) Coetzee, J. F. Prog. Phys. Org. Chem. 1967, 4, 45.

5. Hehre, W. J.; Random, L.; Schleyer, P. V. R.; Pople, J. A. Ab Initio Molecular Orbital Theory; Wiley: New York, 1986; Chapter 4.

6. (a) Taft, R. W. Steric Effect in Organic Chemistry, ed. Newman, M. S.; Wiley: New York, 1956; Chapter 3. (b) Exner, O. Correlation Analysis in Chemistry: Recent Advances; Chapman, N. B., Shorter, J., Eds.; Plenum Press: New York, 1978; p 439.

7. Note that the value of $\Sigma E_{\mathrm{S}}$ is not from $E_{\mathrm{S}}\left(\mathrm{R}_{1} \mathrm{O}\right)+E_{\mathrm{S}}\left(\mathrm{R}_{2} \mathrm{O}\right)$ but from $E_{\mathrm{S}}\left(\mathrm{R}_{1}\right)+E_{\mathrm{S}}\left(\mathrm{R}_{2}\right)$ because of the lack of data for $\mathrm{R}_{\mathrm{i}} \mathrm{O}$. The estimated values of $E_{S}$ for various $\mathrm{R}_{\mathrm{i}} \mathrm{O}$ were employed by the authors in ref. 1.

8. (a) Guha, A. K.; Lee, H. W.; Lee, I. J. Chem. Soc., Perkin Trans. 2 
1999, 765. (b) Dey, N. K.; Hoque, M. E. U.; Kim, C. K.; Lee, B. S.; Lee, H. W. J. Phys. Org. Chem. 2008, 21, 544. (c) Hoque, M. E. U.; Lee, H. W. Bull. Korean Chem. Soc. 2011, 32, 3245.

9. (a) Hoque, M. E. U.; Lee, H. W. Bull. Korean Chem. Soc. 2007, 28, 936. (b) Dey, N. K.; Hoque, M. E. U.; Kim, C. K.; Lee, B. S.; Lee, H. W. J. Phys. Org. Chem. 2009, 22, 425. (c) Dey, N. K.; Lee, H. W. Bull. Korean Chem. Soc. 2010, 31, 1403.

10. Hoque, M. E. U.; Lee, H. W. Bull. Korean Chem. Soc. 2011, 32, 1997.

11. (a) Lee, I. Chem. Soc. Rev. 1990, 19, 317. (b) Lee, I. Adv. Phys. Org. Chem. 1992, 27, 57. (c) Lee, I.; Lee, H. W. Collect. Czech. Chem. Commun. 1999, 64, 1529.

12. The magnitude of $\rho_{\mathrm{XY}}$ value is inversely proportional to the distance between $\mathrm{X}$ and $\mathrm{Y}$ through the reaction center, and the negative sign of $\rho_{\mathrm{XY}}$ implies that the reaction proceeds through a concerted mechanism, while a stepwise mechanism with a ratelimiting leaving group expulsion from the intermediate with the positive sign of $\rho_{\mathrm{XY}}$. The value of $\rho_{\mathrm{XY}}=-0.7$ is a typical one for $\mathrm{S}_{\mathrm{N}} 2$ process. See ref. 11

13. Dey, N. K.; Adhikary, K. K.; Kim, C. K.; Lee, H. W. Bull. Korean Chem. Soc. 2010, 31, 3856.

14. Hoque, M. E. U.; Lee, H. W. Bull. Korean Chem. Soc. 2011, 32, 2109

15. Hoque, M. E. U.; Lee, H. W. Bull. Korean Chem. Soc. 2011, 32, 2805
16. Hoque, M. E. U.; Dey, N. K.; Guha, A. K.; Kim, C. K.; Lee, B. S.; Lee, H. W. Bull. Korean Chem. Soc. 2007, 28, 1797.

17. (a) Williams, A. Free Energy Relationships in Organic and Bioorganic Chemistry; RSC: Cambridge, UK, 2003; Chapter 7. (b) Ruff, A.; Csizmadia, I. G. Organic Reactions Equilibria, Kinetics and Mechanism; Elsevier: Amsterdam, Netherlands, 1994; Chapter 7. (c) Oh, H. K.; Lee, J. M.; Lee H. W.; Lee, I. Int. J. Chem. Kinet. 2004, 36, 434. (d) Oh, H. K.; Park, J. E.; Lee, H. W. Bull. Korean Chem. Soc. 2004, 25, 1041. (e) Oh, H. K.; Ku, M H.; Lee, H. W.; Lee, I. J. Org. Chem. 2002, 67, 8995. (f) Castro, E. A.; Angel, M.; Campodonico, P.; Santos, J. G. J. Org. Chem. 2002, 67, 8911. (g) Castro, E. A.; Pavez, P.; Santos, J. G. J. Org. Chem. 2002, 67, 4494. (h) Oh, H. K.; Ku, M. H.; Lee, H. W.; Lee, I. .J. Org. Chem. 2002, 67, 3874. (i) Castro, E. A.; Pavez, P.; Santos, J. G. J. Org. Chem. 2002, 67, 3129. (j) Castro, E. A.; Pavez, P.; Arellano, D.; Santos, J. G. J. Org. Chem. 2001, 66, 6571. (k) Spillane, W. J.; McGrath, P.; Brack, C.; O’Byrne, A. B. J. Org. Chem. 2001, 66, 6313. (1) Koh, H. J.; Han, K. L.; Lee, H. W.; Lee, I. J. Org. Chem. 2000, 65, 4706. (m) Humeres, E.; Debacher, N. A.; Sierra, M. M. D.; Franco, J. D.; Shutz, A. J. Org. Chem. 1998, 63, 1598. (n) Baynham, A. S.; Hibbert, F.; Malana, M. A. $J$ Chem. Soc., Perkin Trans 2 1993, 1711.

18. Adhikary, K. K.; Lee, H. W.; Lee, I. Bull. Korean Chem. Soc. 2003, 24, 1135 . 